\title{
TU/e EmonOWEN

\section{Improvement of the optical properties of metalorganic chemical vapor deposition grown GaN on sapphire by an in situ treatment}

\section{Citation for published version (APA):}

Haffouz, S., Kirilyuk, V., Hageman, P. R., Macht, L., Wehyer, J. L., \& Larsen, P. K. (2001). Improvement of the optical properties of metalorganic chemical vapor deposition grown $\mathrm{GaN}$ on sapphire by an in situ treatment. Applied Physics Letters, 79(15), 2390-2392. https://doi.org/10.1063/1.1409277

DOI:

10.1063/1.1409277

Document status and date:

Published: 01/01/2001

\section{Document Version:}

Publisher's PDF, also known as Version of Record (includes final page, issue and volume numbers)

\section{Please check the document version of this publication:}

- A submitted manuscript is the version of the article upon submission and before peer-review. There can be important differences between the submitted version and the official published version of record. People interested in the research are advised to contact the author for the final version of the publication, or visit the DOI to the publisher's website.

- The final author version and the galley proof are versions of the publication after peer review.

- The final published version features the final layout of the paper including the volume, issue and page numbers.

Link to publication

\footnotetext{
General rights

- You may freely distribute the URL identifying the publication in the public portal. follow below link for the End User Agreement:

www.tue.nl/taverne

Take down policy

If you believe that this document breaches copyright please contact us at:

openaccess@tue.nl

providing details and we will investigate your claim.
}

Copyright and moral rights for the publications made accessible in the public portal are retained by the authors and/or other copyright owners and it is a condition of accessing publications that users recognise and abide by the legal requirements associated with these rights.

- Users may download and print one copy of any publication from the public portal for the purpose of private study or research.

- You may not further distribute the material or use it for any profit-making activity or commercial gain

If the publication is distributed under the terms of Article $25 \mathrm{fa}$ of the Dutch Copyright Act, indicated by the "Taverne" license above, please 


\title{
Improvement of the optical properties of metalorganic chemical vapor deposition grown GaN on sapphire by an in situ SiN treatment
}

\author{
S. Haffouz, ${ }^{\text {a) }}$ V. Kirilyuk, P. R. Hageman, L. Macht, J. L. Weyher, and P. K. Larsen \\ Experimental Solid Physics III, Research Institute for Materials, University of Nijmegen, Toernooiveld 1, \\ 6525 ED Nijmegen, The Netherlands
}

(Received 8 May 2001; accepted for publication 3 August 2001)

\begin{abstract}
We have studied the effect of an in situ SiN treatment of sapphire substrates on the optical properties of GaN films grown by metalorganic chemical vapor deposition. The SiN deposition, partially covering the substrate, forms a mask for the formation of nanoscale auto-organized $\mathrm{GaN}$ islands. These islands formed upon an increase of the temperature after deposition of a $\mathrm{GaN}$ buffer layer on this mask. A photoluminescence study of the GaN epilayers obtained by lateral overgrowth of these islands shows significant enhancement of the luminescence emission intensity of the near band edge peaks and a reduction of the full width at half maximum of the donor bound exciton $\left(D^{0} X\right)$ peak by $32 \%$ down to $4 \mathrm{meV}$ compared to in our standard process. The GaN films grown using SiN treatment are highly stressed as evidenced by a blueshift of $10 \mathrm{meV}$ in the $D^{0} X$ peak energies. Photoelectrochemical etching in aqueous solution of $\mathrm{KOH}$ was applied to reveal the dislocation density. The density of "whisker-like" etch features, which form due to the presence of dislocations, was reduced from $6 \times 10^{9} \mathrm{~cm}^{-2}$ in standard GaN films to $8 \times 10^{8} \mathrm{~cm}^{-2}$ in the GaN layers grown with the optimized SiN treatment. C 2001 American Institute of Physics. [DOI: 10.1063/1.1409277]
\end{abstract}

The recent spectacular progress in research on III-N materials evidenced by the realization of high performance optoelectronic and microwave devices is related to improvement of the growth of epitaxial material either by metalorganic chemical vapor deposition (MOCVD) or molecular beam epitaxy techniques. Due to the large difference in the lattice parameters and in the thermal expansion coefficient between $\mathrm{GaN}$ and sapphire, the growth of GaN epilayers on this substrate usually takes place in two steps. ${ }^{1,2}$ The standard way of growing $\mathrm{GaN}$ on sapphire includes a nitridation $\operatorname{step}^{3-6}$ and formation of a GaN or AlN buffer layer at low temperature. This buffer layer consists of a high density of small crystallites, which act as nucleation centers for the GaN epilayer. Replacing the high density of small nuclei by a smaller number of bigger islands constitutes an alternative approach to the buffer layer concept. The islands' buffer layer promotes a kind of epitaxial lateral overgrowth, reducing thereby the dislocation density. In order to achieve the formation of such auto-organized islands, recently a growth process $^{7-9}$ based on the insertion of an in situ SiN treatment at high temperature of a sapphire substrate was developed. In this letter, we demonstrate that the optical properties of $\mathrm{GaN}$ epilayers studied by the photoluminescence (PL) technique are considerably improved by SiN treatment and we carry out photoelectrochemical etching in order to reveal the dislocation density.

The PL measurements were performed at low temperature $(4 \mathrm{~K})$ using a $\mathrm{HeCd}$ laser $(325 \mathrm{~nm})$ as the excitation source with power densities up to $50 \mathrm{~W} / \mathrm{cm}^{2}$. The light emitted was dispersed by a $0.6 \mathrm{~m}$ monochromator and detected by a cooled GaAs photomultiplier. The spectral resolution of the measurements was $0.4 \mathrm{meV}$ in the region from 3.2 to $3.55 \mathrm{eV}^{10}$

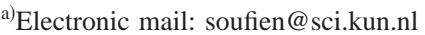

Photoelectrochemical etching was performed in a stirred $\mathrm{KOH}$ solution (0.004 molar) at room temperature. UV illumination was provided by a $450 \mathrm{~W}$ Xe lamp. A $100 \mathrm{~nm}$ thick Ti layer was used to assure photocurrent conduction. ${ }^{11}$

The GaN films studied in this letter were grown in a low-pressure MOCVD (AIX200) machine equipped with a horizontal reactor. A 2 in. rotating susceptor ensured good homogeneity of the material deposition. Before loading, $c$-plane sapphire substrates were chemically cleaned. The growing process started by annealing the substrate at high temperature $\left(1000^{\circ} \mathrm{C}\right)$ under $\mathrm{H}_{2}$ atmosphere for $5 \mathrm{~min}$, then a short nitridation $\left(\mathrm{NH}_{3}\right.$ treatment) was carried out at $1170{ }^{\circ} \mathrm{C}$ using $2.5 \mathrm{slm}$ of $\mathrm{NH}_{3}$. This flow was kept constant in the reactor during the growth process. After that, a $\mathrm{SiN}$ treatment was introduced using silane $\left(\mathrm{SiH}_{4}\right)$ flow of $100 \mathrm{sscm}$ diluted to $50 \mathrm{ppm}$ with $\mathrm{H}_{2}$. The duration of this step was varied from 15 to $120 \mathrm{~s}$. The $\mathrm{GaN}$ buffer layer was deposited at $525^{\circ} \mathrm{C}$, immediately after temperature stabilization. The flow of the gallium precursor (trimethylgallium) was $13.5 \mu \mathrm{mole} / \mathrm{min}$ and the V/III ratio was about 8230 . The thickness of this buffer layer was $30 \mathrm{~nm}$. Finally, a $3 \mu \mathrm{m}$ thick GaN layer was deposited at $1170{ }^{\circ} \mathrm{C}$ using a $64 \mu \mathrm{mol} / \mathrm{min}$ flow of trimethylgallium. Hydrogen was used as the carrier gas, resulting in a growth rate of about $1.70 \mu \mathrm{m} / \mathrm{h}$.

Scanning electron microscopy (SEM) shows that, for a fixed thickness of the buffer layer $(30 \mathrm{~nm})$, the size and the density of GaN islands formed upon increasing the temperature to $1170{ }^{\circ} \mathrm{C}$ were controlled by the $\mathrm{SiN}$ treatment previously reported. ${ }^{7}$ The size of these islands increases when their density decreases and vice versa.

Figure 1 shows the evolution of the near-band edge PL spectra of GaN films with the SiN treatment time (0-120 s). The nontreated sapphire substrate corresponds to the standard growth process. Each PL spectrum consists of the nearband edge emission attributed to the exciton related lumines- 


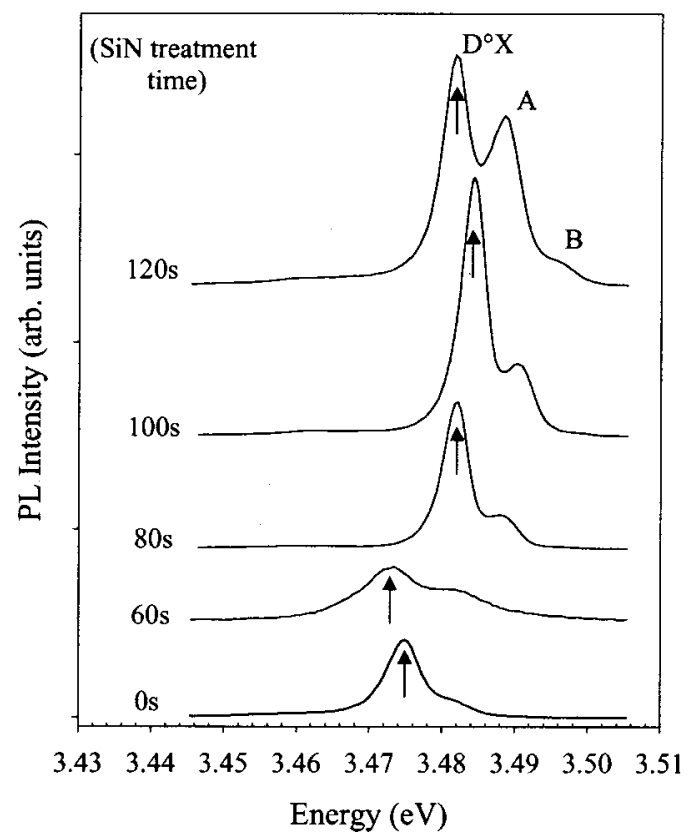

FIG. 1. Evolution of the near-band edge PL spectra at low temperature (4 K) of GaN films with the SiN treatment time $(0-120 \mathrm{~s})$.

cence. Temperature dependence measurements $(4-120 \mathrm{~K})$ combined with reflectivity measurements showed evidence that the dominant line emission in these spectra was related to recombination of donor bound excitons $\left(D^{0} X\right)$ at an energy position between 3.474 and $3.484 \mathrm{eV}$, depending on the SiN treatment time. Only for long SiN treatment times (100 or $120 \mathrm{~s}$ ), can A and B free exciton transitions be observed at the higher energy side of the $D^{0} X$ peak, indicating improvement of the optical quality of these materials.

The full width at half maximum (FWHM) and the energy position of $D^{0} X, A$ and $B$ free excitons' transition vary with the SiN treatment time. In order to clearly illustrate the changes in optical properties we plotted in Fig. 2 the dependence of the FWHM of $D^{0} X$, the energy position of $D^{0} X$, and the $A$ free exciton on the SiN treatment time. Using the standard process, the FWHM of the $D^{0} X$ peak was $5.9 \mathrm{meV}$ but this width rapidly increases to $11 \mathrm{meV}$ for a $\mathrm{SiN}$ treat-

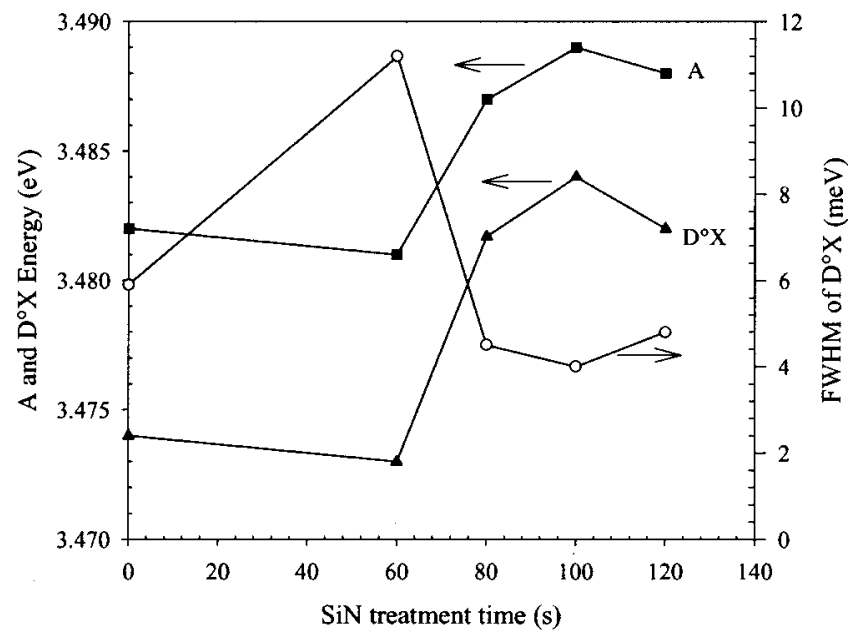

FIG. 2. Variation of the energy position of $D^{0} X$, free $A$ excitons (left scale) and full width at half maximum of $D^{0} X$ (right scale) as a function of the SiN treatment time. The measurements were performed at low temperature (4 K).

Downloaded 31 Oct 2001 to 131.155.192.184. Redistribution subject

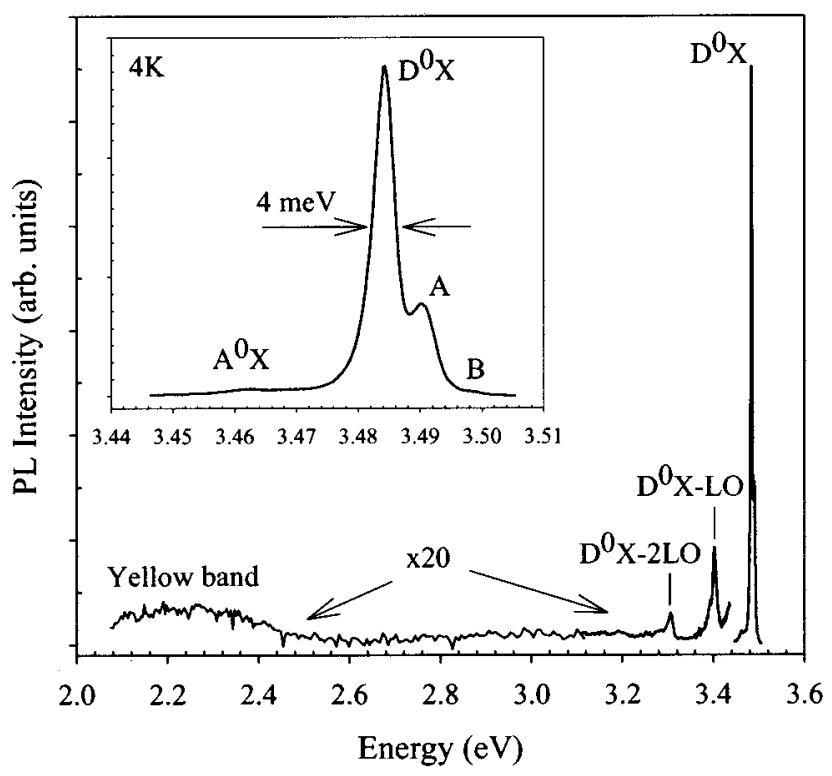

FIG. 3. PL spectra of the GaN sample grown with the optimum SiN time $(100 \mathrm{~s})$ in the range of $3.55-1.8 \mathrm{eV}$ recorded at $4 \mathrm{~K}$.

ment time of $60 \mathrm{~s}$ and then decreases to $4 \mathrm{meV}$ for $100 \mathrm{~s}$. This decrease of about $32 \%$ of the FWHM of $D^{0} X$ compared to in the standard process indicates that the SiN treatment considerably improved the optical properties of GaN.

On other hand, the near band edge peak positions $\left(D^{0} X\right.$ and the $A$ free exciton) were strongly modified by SiN treatment. In fact, the $D^{0} X$ and $A$ free exciton transitions are found at 3.474 and $3.482 \mathrm{eV}$, respectively, for $\mathrm{GaN}$ films grown with the standard process and 3.484 and $3.490 \mathrm{eV}$ for $\mathrm{GaN}$ layers treated for $100 \mathrm{~s}$ by $\mathrm{SiN}$. The blueshift of about 10 and $8 \mathrm{meV}$, respectively, of $D^{0} X$ and $A$ peaks for the GaN layer grown with $\mathrm{SiN}$ treatment is related to the increase of residual stress. ${ }^{12-17}$ Compared to the low temperature unstrained $\mathrm{GaN}$ value of the free $A$ exciton in homoepitaxial $\mathrm{GaN}$ around $3.477 \mathrm{eV},{ }^{18}$ all $\mathrm{GaN}$ epilayers grown in present work are under biaxial compressive strain at low temperature $(4 \mathrm{~K})$. By using the figure showing the stress dependence of the free $A$ exciton transition reported by Gil et al. ${ }^{12,13}$ the biaxial strain is evaluated to be about 0.7 and $1.2 \mathrm{GPa}$ in $\mathrm{GaN}$ grown with the standard process and with $\mathrm{SiN}$ treatment for $100 \mathrm{~s}$, respectively.

The luminescence intensity of the near-band edge was also affected by the $\mathrm{SiN}$ treatment: the $\mathrm{GaN}$ grown with a 100 s SiN treatment time has PL intensity about six times higher than the GaN grown by the standard process. This improvement can be explained by a decrease of the dislocation density, which is known to act as a nonradiative recombinations center. ${ }^{19,20}$

Therefore, from PL measurements it can be concluded that $100 \mathrm{~s}$ is the optimum SiN treatment time because it results in the lowest FWHM of peak transitions and the highest luminescence intensity. Figure 3 shows PL spectra of the $\mathrm{GaN}$ sample grown with this optimum $\mathrm{SiN}$ time in the range of $3.55-1.8 \mathrm{eV}$ recorded at $4 \mathrm{~K}$. The $D^{0} X$ peak, which is located at $3.484 \mathrm{eV}$, was accompanied by two longitudinal optical (LO) phonon replicas at 3.4 and $3.31 \mathrm{eV}$. The sharp line at energy of $3.46 \mathrm{eV}$ is attributed to an acceptor bound exciton transition (labeled $A^{0} X$ ). The donor-acceptor pair to AlP license or copyright, see http://ojps.aip.org/aplo/aplcr.jsp 

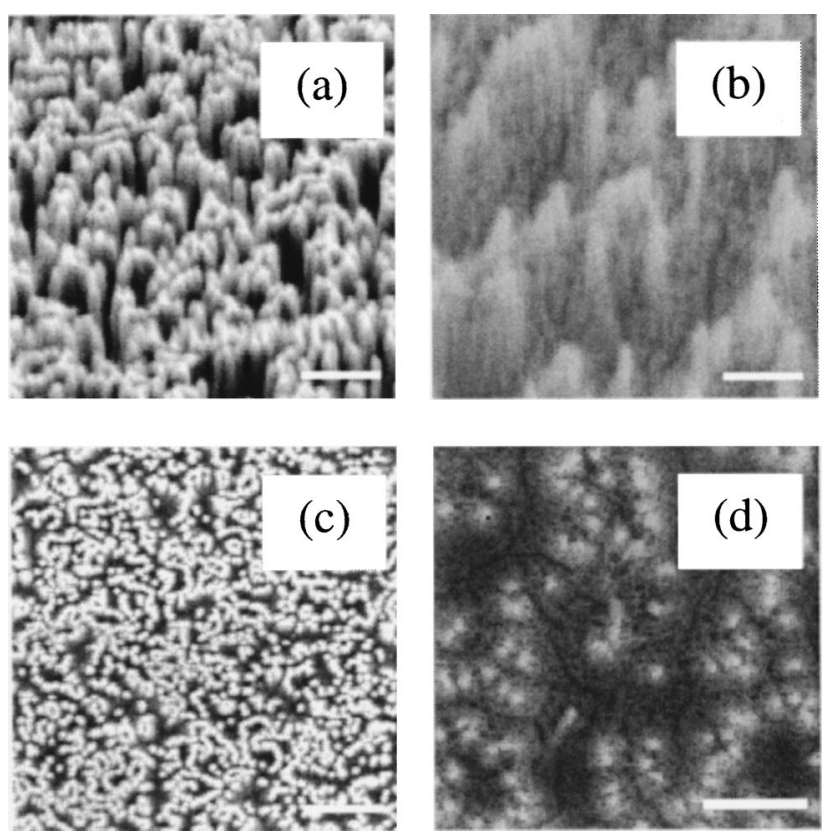

FIG. 4. SEM images of photoelectrochemical etched GaN grown with a standard buffer layer (a), (c) and with the optimized SiN treatment time (b), (d). All markers represent $0.5 \mu \mathrm{m}$.

(DAP) recombination, usually reported at $3.27-3.29 \mathrm{eV}$ is absent which is indicative of the high optical quality of GaN grown by this process. It is important to note that the yellow luminescence (YL) located at $2.24 \mathrm{eV}$ is almost negligible compared to the near-band edge transitions (more than two magnitudes of order lower in intensity).

In order to prove the hypothesis that the dislocation density is lower in the layers grown on this new buffer layer, photoelectrochemical (PEC) etching was performed. Figure 4 shows SEM images of PEC etched GaN films grown with the standard process [Figs. 4(a) and 4(c)] and those with the optimum SiN treatment time [Figs. 4(b) and 4(d)]. The density of filamentary etch features (whiskers) calculated from the images in Figs. $4(\mathrm{c})$ and $4(\mathrm{~d})$ is $6 \times 10^{9}$ and 8 $\times 10^{8} \mathrm{~cm}^{-2}$, respectively. This density is a direct measure of the density of dislocations in GaN epitaxial layers as was demonstrated by calibration of PEC etch features with crosssectional and plan-view transmission electron microscopy (TEM). ${ }^{21,22}$ Detailed TEM analysis of PEC etched samples reported in this letter has confirmed a one-to-one correlation between whiskers and dislocations (both edge and mixed type), ${ }^{23}$ which allows one to conclude that the density of dislocations is remarkably lower in GaN layers grown after $\mathrm{SiN}$ treatment compared with the density in layers obtained using the standard process.
In conclusion, we studied the effect of an in situ $\mathrm{SiN}$ treatment of a sapphire substrate on the optical properties of $\mathrm{GaN}$ epilayers. For the optimized $\mathrm{SiN}$ treatment time (100 s), the FWHM of the $D^{0} X$ transition is $32 \%$ lower and the luminescence intensity of the near band edge is considerably higher compared to in the standard process. PEC etching confirmed that the improvement of the optical properties was accompanied by a reduction in the dislocation density.

This work was financially supported by the Dutch Technology Foundation (STW) and Stichting voor Fundamenteel Onderzoek der Materie (FOM).

${ }^{1}$ H. Amano, N. Sawaki, I. Akasaki, and Y. Toyoda, Appl. Phys. Lett. 48, 353 (1986).

${ }^{2}$ S. Nakamura, Jpn. J. Appl. Phys., Part 1 30, 1705 (1991).

${ }^{3}$ K. Uchida, A. Watanabe, F. Yano, M. Kouguchi, T. Tanaka, and S. Minagawa, J. Appl. Phys. 79, 3487 (1996).

${ }^{4}$ S. Keller, B. P. Keller, Y. F. Wu, B. Heyring, D. Kapolnek, J. S. Speck, U. K. Mishra, and S. P. DenBaars, Appl. Phys. Lett. 68, 1525 (1996).

${ }^{5}$ P. Vennéguès and B. Beaumont, Appl. Phys. Lett. 75, 4115 (1999).

${ }^{6}$ N. Grandjean, J. Massies, and M. Leroux, Appl. Phys. Lett. 69, 2071 (1996).

${ }^{7}$ S. Haffouz, H. Lahrèche, P. Vennéguès, P. De Mierry, B. Beaumont, F. Omnès, and P. Gibart, Appl. Phys. Lett. 73, 1278 (1998).

${ }^{8}$ P. Vennéguès, B. Beaumont, S. Haffouz, M. Vaille, and P. Gibart, J. Cryst. Growth 187, 167 (1998).

${ }^{9}$ S. Haffouz, B. Beaumont, P. Vennéguès, and P. Gibart, The Influence of Growth Mode (2D/3D) on the Physical Properties of GaN Grown by Metal Organic Vapor Phase Epitaxy, III-V Nitride Semiconductors: Growth and Substrate Issues, edited by I. Ferguson and M. O. Manasreh (Gordon and Breach Science, in press).

${ }^{10}$ V. Kirilyuk, A. R. A. Zauner, P. C. M. Christianen, J. L. Weyher, P. R. Hageman, and P. K. Larsen, Appl. Phys. Lett. 76, 2355 (2000).

${ }^{11}$ J. L. Weyher, P. D. Brown, J. L. Rouviere, T. Wosinski, A. R. A. Zauner, and L. Grzegory, J. Cryst. Growth 210, 151 (2000).

${ }^{12}$ B. Gil, O. Briot, and R.-L. Aulombard, Phys. Rev. B 52, R17028 (1995).

${ }^{13}$ B. Gil, F. Hamdani, and H. Morkoç, Phys. Rev. B 54, 7678 (1996).

${ }^{14}$ M. Tchounkeu, O. Briot, B. Gil, J.-P. Alexis, and R.-L. Aulombard, J. Appl. Phys. 80, 5352 (1996).

${ }^{15}$ W. Rieger, T. Metzger, H. Angerer, R. Dimitrov, O. Ambacher, and M. Stutzmann, Appl. Phys. Lett. 68, 970 (1996).

${ }^{16}$ M. Leroux, B. Beaumont, N. Grandjean, P. Lorenzini, S. Haffouz, P. Vennéguès, J. Massies, and P. Gibart, Mater. Sci. Eng., B 50, 97 (1997).

${ }^{17}$ S. Dassonnevile, A. Amokrane, B. Sieber, J.-L. Farvacque, B. Beaumont, and P. Gibart, J. Appl. Phys. 89, 3736 (2001).

${ }^{18}$ R. Stepniewski, K. P. Korona, A. Wysmolek, J. M. Baranowski, K. Pakula, M. Potemski, G. Martinez, I. Grzegory, and S. Porowski, Phys. Rev. B 56, 15151 (1997).

${ }^{19}$ S. J. Rosner, E. C. Car, M. J. Ludowise, G. Girolami, and H. I. Erikson, Appl. Phys. Lett. 70, 420 (1997).

${ }^{20}$ T. Sugahara, H. Sato, M. Hao, Y. Naoi, S. Kurai, S. Tottori, K. Yamashita, K. Nishino, L. T. Romano, and S. Sakai, Jpn. J. Appl. Phys., Part 2 37, L398 (1998).

${ }^{21}$ C. Youtsey, R. T. Romano, and I. Adesida, Appl. Phys. Lett. 73, 797 (1998).

${ }^{22}$ C. Youtsey, R. T. Romano, R. J. Molnar, and I. Adesida, Appl. Phys. Lett. 74, 3537 (1999).

${ }^{23}$ J. L. Weyher, F. D. Tichelaar, H. W. Zandbergen, L. Macht, and P. R. Hageman (unpublished). 